\title{
Behavior of the Aviation Engine Control System During the Transition to the Lorenz Attractor
}

\author{
S.S. Tovkach \\ National Aviation University, 1, Lubomyr Husar Ave., 03058 Kyiv, Ukraine
}

(Received 10 January 2021; revised manuscript received 15 February 2021; published online 25 February 2021)

\begin{abstract}
The article considers the Lorentz attractor in aviation engine control systems (AECS) to obtain the necessary characteristics of the starting system and the laws of fuel supply, and to determine the emission characteristics. The defined behavior of the control system allows to optimize the control program of adjustable elements of the flowing part of the gas generator in transition modes of operation; to get a full picture of the starting characteristics of the developed engine, including reserves of gas-dynamic stability (GDS) in the starting modes; to establish the necessary programs for regulating the guide devices (GD), air bypass from the compressor; to select the required starter power, start-up cycle and fuel supply program in ground, alpine and flight conditions at the expected temperatures of air, fuel and oil in operation. Euler's and Runge-Kutta methods, Lorentz attractor are considered as the main approaches to mathematical modeling of AECS. The script of the interface of the modeling program includes the possibility of two-level modeling of the flowing part with the properties of end-to-end automated calculation: input of initial data and calculation of thermodynamic parameters of the engine; design of the flowing part of the engine based on the node approach; strength design and mass analysis; export data to files for CAD systems for further processing and interpretation.
\end{abstract}

Keywords: Lorenz attractor, Aviation engine, Electronic control system, Transition process, Distributed system, Differential equations, Mathematical modeling.

DOI: 10.21272/jnep.13(1).01010

PACS number: 07.05.Tp

\section{INTRODUCTION}

Modern requirements for the mathematical description of the engine and its properties at the initial stage of design allow at the stage of choosing its technical form as optimization variables to use indicators such as the number of stages of turbomachines, number of blades, power scheme, material range and indicators characterizing the engine as a real design $[1,2]$.

To determine the geometric accounting and mass data of aviation gas turbine engines, software is used that is based on generalized dependencies that take into account the influence of basic process parameters and engine dimensions on its mass, in simple engine mass models and on nodal mass models in detailed approaches. It is necessary to develop a mathematical model of the geometric shape and mass of the engine using detailed information about the basic components and parts of the engine.

The basis of the program of detailed modeling of the engine is a node program, which includes subroutines of thermodynamic calculation, construction of flowing parts of the engine nodes on the basis of generalized representations.

To increase the level of detail of the engine, the basic program must be supplemented by a block of lead calculation of vane machines in the calculation mode.

Necessary changes with the lead description of the vane machines are made in the thermodynamic model of the engine.

The source data for the calculation are the source data used in the node model of the engine. In addition, the distribution of work and efficiency by stages for each blade machine, the values of selections and leaks of the cooling turbine air at the lead level are set. Initial approximations for the new independent variables are formed when performing the lead calculation of axial turbomachines on the average radius in the calculation mode before the lead thermodynamic calculation of the engine.

According to the results of the calculation of this model, the source data are both traditional data on the nodal model and the distribution of thermodynamic parameters, works and efficiency in separate stages for each of the paddle machines. The calculated data will be useful for the next design lead calculation of axial turbomachines on the average radius in the calculation mode.

Thermodynamic model of the engine with a lead description of the vane machines [3, -4] allows more accurate modeling of the system of selection and supply of cooling air turbine.

The engine and its components are represented by components of elementary objects, which are simplified representations of real engine parts. The level of correspondence of elementary objects to real ones increases with the development of versions of the program.

The geometric dimensions of elementary objects are determined by calculating and linking the flow part. External software components are used to more accurately determine the shapes of objects, taking into account a detailed calculation of strength (for example, turbomachine disks), thus implementing the concept of multilevel multidisciplinary modeling.

It is advisable to use an object-oriented approach, which allows you to determine the number and changes in the properties of both the most elementary objects and groups of objects with varying degrees of generalization (rotor, stator, compressor, gas generator).

Great contribution to the development of aviation engine control system has been made by the scientists: Yu.M. Tereshchenko, V.A. Boguslaev, M.M. Mitrakhovich, 
K.I. Gyadunov, A.N. Kozlov, M.L. Nemchikov, I.S. Melnikova, Wirma Yuliana, Anita Maharani, Zainur Hidayah, Daqing Liu, Lijun Yuan, Lei Kuang, Iwona Komorska, A. Vinogradov, Clovis Kohyep Pilla [1, 3-9] and SNECMA, Rolls-Royce, MTU Enterprises within the project OBIDICOTE (On Board Identification Diagnosis and Control of gas Turbine Engine).

The aim of this research is to define the special methods and processes of mathematical modeling the aviation engine control system taking into account the influence of electromagnetic, emission characteristics, thermodynamic parameters of the flowing part of the engine and other interferences.

\section{METHOD FOR TRANSITION PROCESS ANALYSIS IN THE AVIATION ENGINE CONTROL SYSTEM}

\subsection{Difference Equations Technique}

The ordinary differential equation of the first order explicitly for aviation engine diagnostics and control system has the form $\frac{d y}{d x}=F(x, y)$ [3]. The solution of this differential equation is the function $y(x)$. Unambiguously, the solution of a differential equation can be found only under known initial conditions, which together with the equation itself constitutes the Cauchy problem. That is, having solved the Cauchy problem, there is no longer a general solution, but a partial one.

The numerical method for solving the Cauchy problem is to find the values of the function sequentially at the following points, based on the previous ones [5]. For sampling, i.e. the method of transition from $i$ to $i+1$ points, use different approaches: single-step methods, Runge-Kutta methods, multi-step methods.

\subsection{Euler Method for Transition Process Analysis}

Consider the problem of cooling the engine elements (e.g., turbines), according to the law of heat radiation: $\frac{d y}{d t}=-k(y-Z)$. The cooling rate of an element in air is proportional to the difference between body and air temperatures, where $y$ is the body temperature, $Z$ is the air temperature, and $k$ is the proportionality factor.

Consider Euler's numerical scheme [6,7]. Suppose we need to solve the equation $\frac{d y}{d x}=f(x, y)$ on the interval $a \leq x \leq b$ with the initial condition $y(a)=y_{0}$. The final-difference method is that we divide the interval $[a, b]$ into $N$ segments. To solve the problem it is necessary, starting from the starting point, to go with the step $h=\frac{b-a}{N}$, finding all newer values of the function. In this case, $x(k)=a+k h,(k=0,1 \ldots N)$, and Euler's iterative scheme takes the form:

$y_{0}=y_{0} ; y(k+1)=y(k)+h f(x(k), y(k)), \quad k=0,1 \ldots N-1 ;$

i.e. the solution $y(k+1)$ at the next point is located as a segment of the tangent drawn at the point $x(k)$
(Fig. 1). Euler's scheme arises from Taylor's decomposition around the point $x_{k}: y\left(x_{k+1}\right)=y\left(x_{k}\right)+h y^{\prime}\left(x_{k}\right)$ by neglecting terms with derivatives older than the first.

The geometric content of Euler's method in the approximation of the solution on the segment $\left[x_{k}, x_{k+1}\right]$ by the tangent segment drawn to the solution graph at the point $x_{k}$ (see Fig. 1).

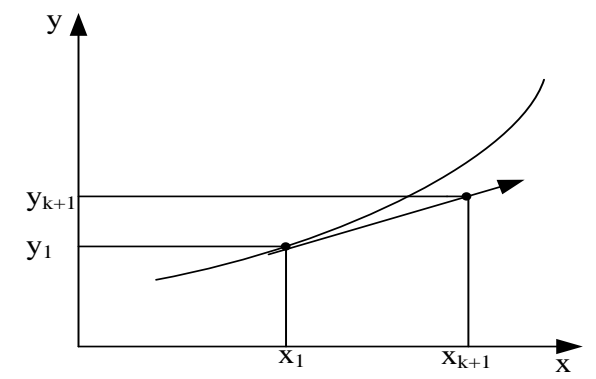

Fig. 1 - The geometric content of Euler's method [5]

This approach must be implemented for the problem of cooling the turbine to temperature $Z$.

\subsection{Runge-Kutta Methods for Transitions Process Analysis}

The derivatives are approximated by the values of the function $f(x, y)$ at points on the interval $\left[x_{0}, x_{0}+h\right]$, which are selected from the condition of maximum proximity of the algorithm to the Taylor series.

Depending on the senior power $h$, which takes into account the members of the series, Runge-Kutta computational schemes of different order are constructed.

For example, the scheme for the second order of accuracy has the form:

$$
y\left(x_{0}+h\right)=y_{0}+\frac{h\left(f\left(x_{0}, y_{0}\right)+f\left(x_{0}+h, y_{0}+h f_{0}\right)\right)}{2} .
$$

Improving the accuracy of the calculation is achieved by using polynomial circuits. The fourth-order Runge-Kutta scheme consists in crushing the transition from $x(k)$ to $x(k+1)$ into four stages. With,

$$
\begin{aligned}
& y(k+1)=y(k)+\frac{h}{6}\left(k_{1}+2 k_{2}+2 k_{3}+k_{4}\right) ; \\
& k_{1}=f(x(k), y(k)) ; \\
& k_{2}=f\left(x(k)+\frac{h}{2}, y(k)+\frac{h}{2} k_{1}\right) ; \\
& k_{3}=f\left(x(k)+\frac{h}{2}, y(k)+\frac{h}{2} k_{2}\right) ; \\
& k_{4}=f\left(x(k)+h, y(k)+k_{3} h\right) .
\end{aligned}
$$

\subsection{Optimization Method of Engine Transition Process}

The same Euler method is used to solve the system of differential equations in the case to analyze the transition process of aviation engine control system and create the optimization criteria, when the solutions for the functions $x(t)$ and $y(t)$ in the next step $t+d t$ are calculated through the values in the previous step $t$. 


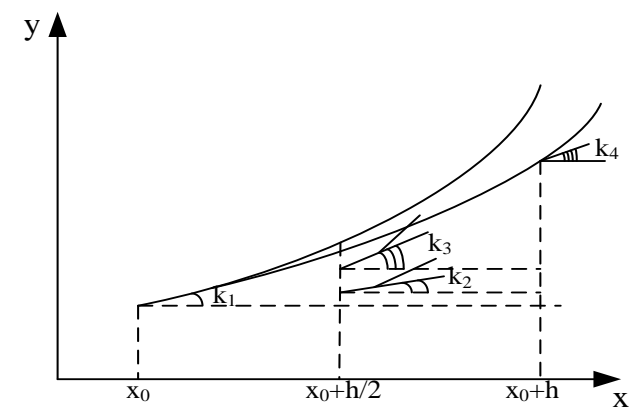

Fig. 2 - The geometric content of Runge-Kutta scheme [5]

To start the calculations, it is necessary to know the initial conditions $x(0)$ and $y(0)$.

An investigation of the development of the "best individual - current individual" population. The population "best individual - current individual" can be described by a system of equations:

$$
\left\{\begin{array}{l}
\frac{d x}{d t}=k_{1} x+k_{2} x y \\
\frac{d y}{d t}=k_{3} y+k_{4} x y,
\end{array}\right.
$$

where $k_{1}>0 ; k_{2}<0 ; k_{3}<0 ; k_{4}>0$. Initial conditions: $x=x_{0}=80 ; y=y_{0}=30$.

The population of current individual $x(t)$ is described by the rules:

1. Appearance rate of current individual $x_{b}$ and its disappearance $x_{d}$ is the constants: $x_{b}>x_{d}$. That is, without best individuals, the current individuals would grow at a rate of $\left(x_{b}-x_{d}\right) x=k_{1} x$.

2 . The number of cases where a best individual destroys a current individual is proportional to the number of their encounter, i.e. $x \cdot y$.

The population of best individuals is described by the rules:

1. The disappearance factor depends on deteoriation of characteristics $k_{3} \cdot y$.

2. Meeting with a current individual with a probability of $x \cdot y$ leads to an increase in the number of best individuals.

Equations of this type are derived in the works of Lotka and Voltaire [7].

1. Investigate the model by finding the dependences of the number of hares $\mathrm{x}$ and wolves $\mathrm{y}$ over time, as well as the dependence of the number of hares on the number of wolves (phase trajectory). The calculations should be performed with different initial values.

2. Check that the stationary point will be.

3. Check how the solution depends on the differentiation step $H$ (especially the phase trajectory).

Suppose we need to solve a type equation $\frac{d^{2} x}{d t^{2}}=F\left(t, x, x^{\prime}\right)$. To do this, we describe this equation as a system of two first-order differential equations with the corresponding initial conditions for $x_{0}$ and $V_{0}=\frac{d x(0)}{d t}$ :

$$
\left\{\begin{array}{l}
\frac{d x}{d t}=V \\
\frac{d V}{d t}=F(x, t, V)
\end{array}\right.
$$

To solve this system based on Euler's scheme, we first find a new value of $V=V+F d t$, and then a new value of $x=x+V d t$.

One of the more accurate methods for solving such equations is the modified Euler method, when the obtained values of the function and its derivative are used as initial data for the next time step according to the scheme:

Step 1: Looking for a new speed value:

$$
V^{\prime}(i+1)=V(i)+d t \frac{F(x(i))}{m} .
$$

Step 2: Look for a new coordinate value:

$$
x(i+1)=x(i)+\frac{2 d t}{\left(V^{\prime}(i+1)+V(i)\right)} .
$$

It is possible and 3 step of specification of speed:

$$
V(i+1)=\frac{V(i)+V^{\prime}(i+1)+d t \frac{F(x(i+1))}{m}}{2},
$$

where the force $F(x(i+1))$ is calculated taking into account the change in the coordinate.

3 (or 4 step): $t(i+1)=t(i)+d t$ and everything repeats again, i.e. the speed $V(i)$ becomes $\mathrm{V}^{\prime}(i+1)$ or $\mathrm{V}(i+1)$ (for the case of step 3). Step 3 is introduced to increase the accuracy of the calculation when the object moves in complex or strongly changing fields.

\subsection{The Transition of Chaos in the Aviation Engine Control System. Lorenz attractor}

As can be seen from the "best individual-current individual" model, both stationary solutions and closed trajectories (boundary cycles) are possible when solving systems of differential equations. Such solutions are called attractors (attracting sets) on the basis that the specific solution of the equation converges to the attractor in the region of attraction of which it falls. It turns out that chaotic solutions are also possible, i.e. it is impossible to predict in advance in what state the system will be after some time. This is due to the large distortions of the decision with minor deviations in the initial conditions or in the decision itself in the previous step over time.

Lorenz proposed one of the first models of chaotic behavior of completely deterministic equations. The Lorentz system describes the relationship between the velocity of object $X$ with the values of $Y$ and $Z$, which characterize the temperature of the system:

$$
\begin{aligned}
& \frac{d x}{d t}=\sigma y-\sigma x ; \\
& \frac{d y}{d t}=-x Z+r x-y ; \\
& \frac{d Z}{d t}=x y-b Z
\end{aligned}
$$


Here $r=\frac{R}{R_{c}}$, where $R$ is the Rayleigh number; $\sigma$ is the Prandtl number, $b$ is a constant $\left(b=\frac{8}{3}\right)$.

The program to solve this problem is written in the programming language in the training compiler:

begin

Series1.Clear; Series2.Clear; Series3.Clear; $y:=0 ; z:=0 ; b b:=$ true; $d t:=0.001$;

$\mathrm{t}:=0 ;$ sigma: $=5 ; r:=15$;

$x:=$ strtofloat(Form1.Edit2.Text); while $b b$ do
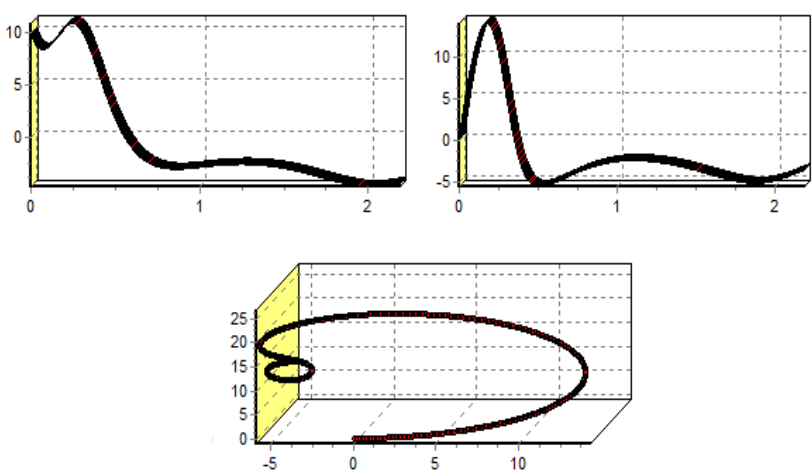

Fig. 3 - Engine transition process with the number of iterations is 10 (from the left side) and 100 (from the right side)
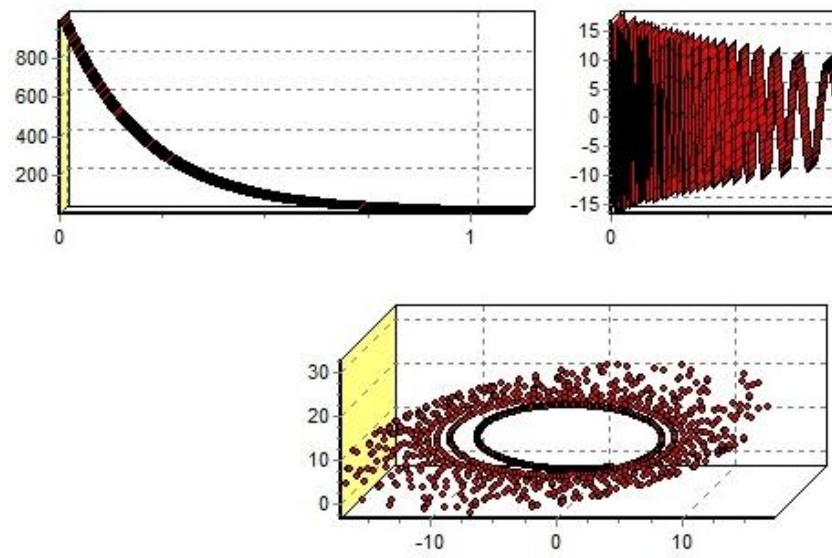

Fig. 4 - Engine transition process with the number of iterations is 1000

\section{CONCLUSIONS}

In recent years, for mathematical modeling of the aviation engine control system and its elements, the input factors have been used that directly determine the mass of nodes (geometric dimensions, external loads and operating conditions), the possibility of constructing more objective communication equations, which increases the accuracy of such models (about $10 \%$ ) and the possibility of their use to predict the properties of new engines and their control systems.

The coefficients in the coupling equations, as in the previous level models, are determined on the basis of statistics with the mass of the engine components. The need for more detailed input complicates the process of

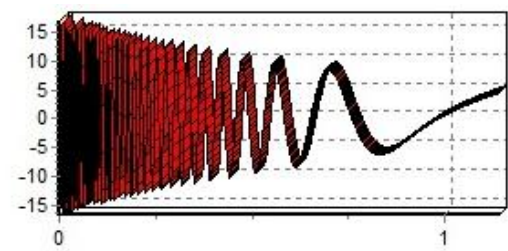

begin

$x:=x+(\operatorname{sigma} \cdot y-\operatorname{sigma} \cdot x) \cdot d t$

$y:=y+(-x \cdot z+r \cdot x-y) \cdot d t$

$z:=z+(x \cdot y-b \cdot z) \cdot d t$

Series1.AddXY $(t, x)$;

Series2.AddXY $(t, y)$;

Series3.AddXY $(y, z)$

$t:=t+d t$

Application.ProcessMessages;

end;

end;

procedure TForm1.BitBtn2Click(Sender: TObject);

begin

$b b:=$ false;

end;

end.
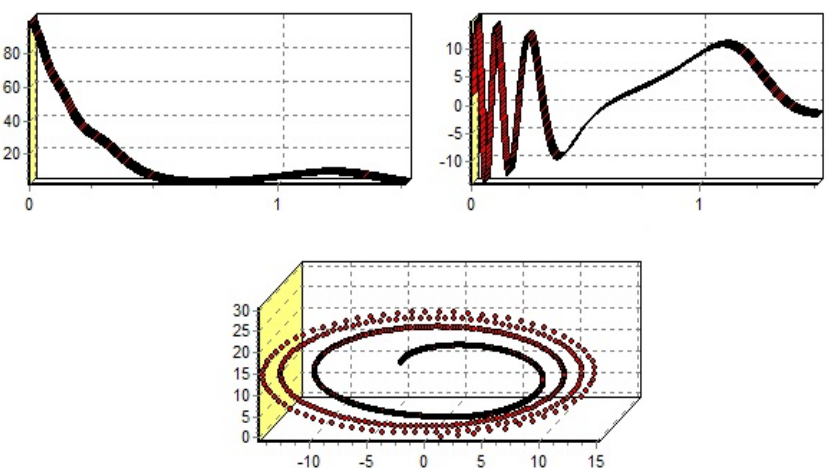

1 determining the mass of the designed engine with the specified parameters and determines the preliminary connection of nodes in the engine system. As a result, the geometric dimensions, the number of steps, circumferential velocities, and other indicators that meet the specified constraints are determined.

As a result of calculation of parameters and weight of elements of the engine from conditions of maintenance of the set efficiency and durability of the design, the basic indicators characterizing aviation engine control system nodes (the number of blades in stages of the compressor and the turbine, contour loading of disks, geometrical sizes of blades of the stator and the rotor) are defined.

Based on this information, the strength of the struc- 
tural elements of the engine, the volume and mass of the elements that are part of the node, and then the nodes and the engine as a whole $[8,10]$ were calculated:

$$
m_{\partial в}=\sum_{i=1}^{\mathrm{N}} \sum_{\mathrm{j}=1}^{\mathrm{K}_{\mathrm{i}}} m_{i j}
$$

where $m_{i j}$ is the mass of the $j$-th element of the $i$-th engine unit; $K i$ is the number of elements in the $i$-th node of the engine control system; $N$ is the number of engine components.

\section{REFERENCES}

1. Yu.M. Tereshchenko, V.A. Boguslaev, E.V. Doroshenko, I.F. Kravchenko, I.A. Lastivka, M.M. Mitrakhovich, Yu.Yu. Tereshchenko, Aerodynamics of compressors of gas turbine engines with gas dynamic flow control: monograph, 408 (Zaporizhzhia: 2019) [in Russian].

2. S.S. Tovkach, J. Nano- Electron. Phys. 12 No 1, 01003 (2020).

3. K.I. Gyadunov, A.N. Kozlov, M.L. Nemchikov, I.S. Melnikova, Civil Aviation High Technol. 22 No 3, 35 (2019).

4. Wirma Yuliana, Anita Maharani, Zainur Hidayah, Int. J. Business Econom. 4 No 2, 160 (2020).

5. Daqing Liu, Acta Geotechnica 15 No 6, 325 (2020).
Methods of this type require the preliminary design of the components at the element level and their subsequent connection in the engine system. They determine the accuracy of about $5 \%$ and allow to solve problems of rational design of the engine with minimization of its mass in CAD.

The experimental results for the Lorenz attractor with template and iterate procedures in the form of programming language and graph solution have been presented.

\title{
Поведінка системи керування авіаційним двигуном під час переходу на атрактор Лоренца
}

6. Lijun Yuan, Ya Xan Lu, J. Opt. Soc. Am. 28 No 9, 2265 (2011).

7. Lei Kuang, Shouzheng Zhu, Jianjun Gao, Int. J. Anten. Propag. 2014 No 2, 1 (2014).

8. Z. Wolezynski, Iwona Komorska, A. Borczuch, IOP Conf. Ser.: Mater. Sci. Eng. 421 No 2, 002042 (2018).

9. S.S. Tovkach, 2020 IEEE $6^{\text {th }}$ International Conference Methods and Systems of Navigation and Motion Control: proceedings, 69 (2020).

10. A. Vinogradov, Renet Badykov, Clovis Kohyep Pilla, Res. J. Appl. Sci. 9 No 11, 789 (2014)

\section{С.С. Товкач}

\author{
Національний авіаційний університет, пр. Люболира Гузара, 1, 03058 Київ, Україна
}

\begin{abstract}
У статті розглядається атрактор Лоренца в системах керування авіаційних двигунів (СКАД) для отримання необхідних характеристик пускової системи та законів подачі палива; визначення емісійних характеристик. Визначена поведінка системи керування дозволяе оптимізувати програму керування регульованими елементами проточної частини газогенератора на перехідних режимах роботи; отримати повне уявлення про пускові характеристики розроблюваного двигуна, включаючи запаси газодинамічної стійкості (ГДС) на режимах запуску, та встановити необхідні програми для регулювання напрямних апаратів (НА), перепуску повітря із компресора; вибрати необхідну потужність стартера, циклограму запуску та програму подачі палива в наземних, високогірних та польотних умовах при очікуваних температурах повітря, палива та мастила в експлуатації. Метод Ейлера, Рунге-Кутта, атрактор Лоренца визначаються основними підходами до математичного моделювання СКАД. Сценарій інтерфейсу програми моделювання включае можливість дворівневого моделювання проточної частини із властивостями наскрізного автоматизованого розрахунку: введення вихідних даних та обчислення термодинамічних параметрів двигуна; проектування проточної частини двигуна на основі вузлового підходу; міцнісне проектування та аналіз маси; експорт даних у файли для CAD-систем для подальшої обробки та інтерпретації.
\end{abstract}

Ключові слова: Атрактор Лоренца, Авіаційний двигун, Електронна система керування, Перехідний процес, Розподілена система, Диференціальні рівняння, Математичне моделювання. 